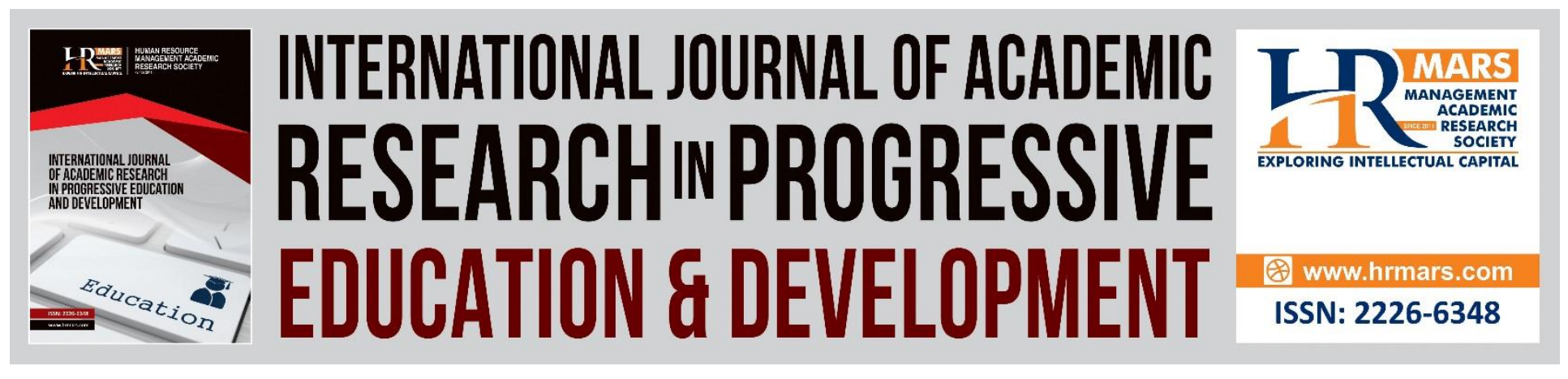

\title{
Attribute Assessment Instrument on Communication Skills, Leadership and Teamwork among students in Faculty of Sports Science and Coaching, UPSI
}

Ahmad Hashim, Thariq Khan Azizuddin Khan, Zulakbal Abd Karim \& Norhazira Abdul Rahim

To Link this Article: http://dx.doi.org/10.6007/IJARPED/v8-i1/5528

DOI: $10.6007 /$ IJARPED/v8-i1/5528

Received: 04 Jan 2018, Revised: 21 Feb 2019, Accepted: 02 March 2019

Published Online: 08 March 2019

In-Text Citation: (Hashim, Khan, Karim, \& Rahim, 2019)

To Cite this Article: Hashim, A., Khan, T. K. A., Karim, Z. A., \& Rahim, N. A. (2019). Attribute Assessment Instrument on Communication Skills, Leadership and Teamwork among students in Faculty of Sports Science and Coaching, UPSI. International Journal of Academic Research in Progressive Education and Development, 8(1), 64-74.

Copyright: (C) 2019 The Author(s)

Published by Human Resource Management Academic Research Society (www.hrmars.com)

This article is published under the Creative Commons Attribution (CC BY 4.0) license. Anyone may reproduce, distribute, translate and create derivative works of this article (for both commercial and non-commercial purposes), subject to full attribution to the original publication and authors. The full terms of this license may be seen at: $\underline{\text { http://creativecommons.org/licences/by/4.0/legalcode }}$

Vol. 8, No. 1, 2019, Pg. 64 - 74

http://hrmars.com/index.php/pages/detail/IJARPED

JOURNAL HOMEPAGE

Full Terms \& Conditions of access and use can be found at http://hrmars.com/index.php/pages/detail/publication-ethics 


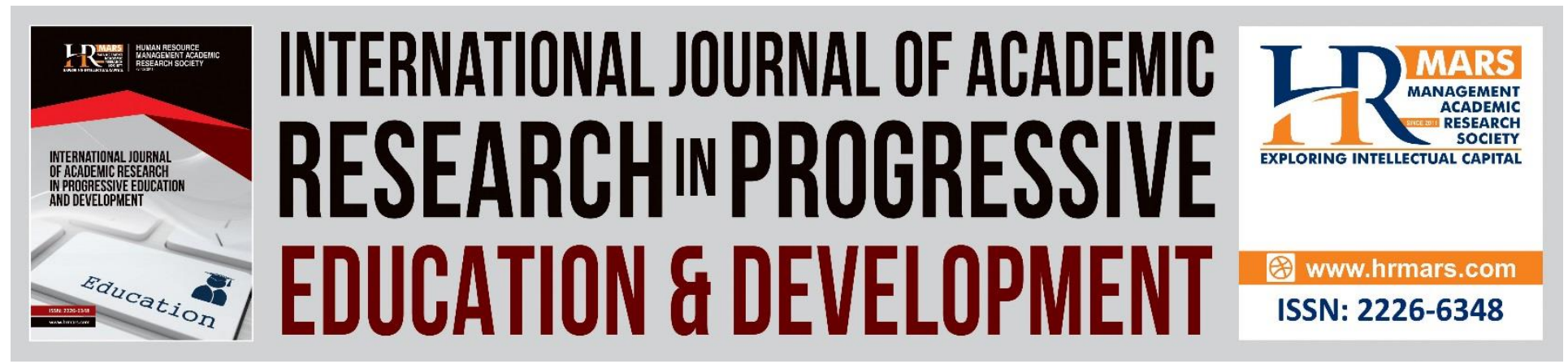

\title{
Attribute Assessment Instrument on Communication Skills, Leadership and Teamwork among students in Faculty of Sports Science and Coaching, UPSI
}

\author{
Ahmad Hashim, Thariq Khan Azizuddin Khan, Zulakbal Abd \\ Karim \& Norhazira Abdul Rahim \\ Faculty of Sports Science and Coaching, Universiti Pendidikan Sultan Idris, 35900, Tanjong \\ Malim, Perak \\ Correspondence Author Email: ahmad@fsskj.upsi.edu.my
}

\begin{abstract}
The purpose of this study is to design a questionnaire instrument for an attribute assessment on communication skills, leadership and teamwork for the students in Faculty of Sports Science and Coaching, Sultan Idris Education University (UPSI), Malaysia. Four variables are used to measure the attributes of communication skills, leadership and teamwork, including oral communication, written communication, leadership and teamwork. A number of 212 Sports Science students have been selected as the study sample. The study analysis uses Cronbach's alpha test to obtain reliability of the instrument. Factor analysis is also used to obtain validity on social skill and responsibility instruments. Finding from the factor analysis shows that only 59 questionnaires items from the overall 65 items are valid for the assessment. All of the assessment items on communication skills, leadership and teamwork questionnaires obtained high reliability value which is $r=.93$.
\end{abstract}

Keywords: Communication Skills, Leadership Skills and Teamwork Skills

\section{INTRODUCTION}

Higher education system as outlined by the Ministry of Higher Education has its own vision and mission on successful outcome and good interest of every students. The Ministry of Higher Education has also emphasized on the importance of giving equal priority on both knowledge and morality. The Malaysia Education Blueprint 2015-2025 (Ministry of Higher Education, 2015) is intended to meet student aspirations that include ethics and spirituality, leadership skills, national identity, language skills, thinking skills and knowledge. We are now in the era of facing the 4.0 education revolution which is increasingly challenging to all parties. The latest 
development in industrial technology such as artificial intelligence, intelligence machines, cloud technology and robotics will certainly give a big challenge to all graduates. In this regard, UPSI students at the Faculty of Sports Science and Coaching (FSSK) need to be educated and guided in preparation for a challenging future. They should be well-equipped with solid knowledge and empowered with balanced ethical and spiritual values.

The Ministry of Higher Education (2016) has pointed out that each graduate must master and possess the features outlined in the Learning Outreach Domain (DHP) from the Malaysian Qualifications Framework, among which are mastery of knowledge, competency in practical or physical skills as well as capability in social skills and responsibilities. The Malaysia Education Blueprint 2015-2025 (MHE 2015) is designed based on the vision and aspirations in educating talented, skilled and knowledgeable students who are fully prepared to face the challenges in the 21st century. The Development Plan aims to develop a holistic, balanced and entrepreneurial graduates in line with the National Education Philosophy. One of the MHE initiatives is the implementation of an integrated assessment system that reveals holistic achievement of students as a result of learning experience. Integrated Cumulative Grade Value Assessment (Integrated CGPA) aims to drive constructive alignment practices to ensure the curriculum design, curriculum implementation and assessment process at the course and program level are of high quality. Integrated CGPA is a system or mechanism for evaluating and reporting on integrated student enhancement and development in the aspect of manners (ethics and noble values), declarative and functional knowledge and their technical skills in discipline. This mechanism aims to help stakeholders plan and determine the most aligned steps of improvement. Integrated CGPA Reporting also demonstrate a holistic achievement of students as well as their achievements for each program's learning outcomes throughout the course of study.

To ensure the success of Integrated CGPA reporting, an instrument for attribute assessment on Learning Outcome Domain (LOD) from the Malaysian Qualification Framework (MQF) should be developed and validated so that it can be utilized to assess performance that are holistic, entrepreneurial and balanced. This study aims at developing and determining the attribute assessment instrument validity for LOD of MQF targeted at UPSI students from the Faculty of Sports Science and Coaching. The construct of this assessment instrument is based on Social Skill and Responsibility attributes. There are three important goals in Malaysian Higher Education, which is first to give priority to human capital development in providing skilled manpower and capable of facing future challenges. Secondly, to fulfill the aspirations of students in ethical and spiritual aspects, leadership skills, national identity, language skills, thinking skills and knowledge. Hamat and Nordin (2012) have emphasized that human capital development is an effort towards creating knowledgeable, skilled, innovative, self-employed, ethical, educated, well-trained and employed, possessed high moral values, well-mannered, courteous, disciplined, dynamic, innovative, creative, patriotic, fair, progressive, determined and competitive.

The human capital development has its own educational goals to enhance personality and holistically develop students' ability through the learning of specialized skills, realizing their intellectual, physical and spiritual capabilities and generating excellent human capital. To achieve 
remarkable quality of human capital development, therefore this endeavour requires a holistic approach and emphasizes on the development of knowledge, thinking skills, leadership skills, bilingual skills, spiritual ethics and national identity. The UPSI Sports Science Curriculum, as offered at the Faculty of Sports Science and Coaching namely Physical Education, Coaching Science, Rehabilitation Science and Sports Psychology will generate students with excellent human capital characteristics. The curriculum and co-curricular activities designed will also create a more cheerful and enjoyable learning climate and culture thus bringing positive impact to the students (Nurul Haerani Mohamad \& Ahmad Esa, 2013). Active student participation in curriculum and co-curricular activities such as uniformed bodies, associations, clubs and sports are important for them to build their personality and leadership qualities. The holistic student development requires involvement in both academic and co-curricular areas. Students will learn and embrace leadership qualities, ethics and spirituality, leading skills, national identity, language skills, thinking skills and knowledge.

Good education will ensure that graduates continue to be relevant to the current market requirements. Moreover, graduates will be more prepared to gear themselves up for a more challenging and competitive environment realizing that present global economic climate is now in the era of knowledge-based economy which mostly focus on science and technology. Considering impression by future employers and increasing job demands, graduates need to possess not only academic qualifications but also capabilities and skills as an added value to engage employers' attention (Rinaldi, Hamzah \& Nordin, 2015). Mohamad and Esa (2013) in their study argued that human capital development is not limited only to academic discipline and skill enhancement alone, but also includes development of mind, spiritual, personality and ethics. Human capital with these features ensure that transformation and development of individuals, families, communities, nations and the world would take place in a more structured manner. According to Jalil (2014), well-organized human capital development will create a knowledgeable and highly skilled workforce. The development of human capital however is not limited to the discipline and skills enhancement alone. It also includes growth of mind, spiritual, personality and ethics.

The development of human capital in education will focus on personality enhancement of graduates to produce a balanced human capital in terms of skills, patriotism, discipline and pure value towards the creation of a human capital of a nation with towering personality. Human capital assessment carried out in the faculty curriculum will further boost the national education system. Ahmad (2015) in his research stated that testing, measurement and evaluation are important components in the learning and teaching process. Results from study measurements and assessments can provide educators with information on the effectiveness of the approach, strategy or technique used. As for the graduates, it is an indicator of what they have learned, what to learn and how best to learn something from the curriculum activity.

The construct of this questionnaire measurement instrument is based on self-assessment method. It can be defined as graduates evaluating their own work based on the criteria outlined (Prihamdani, 2016). Maskan (2013) in his work addressed that self-assessment in curriculum activities is an important tool to improve academic performance and ability. Learning will 
improve with self-assessment because it meets the learning objectives to be measured (Daniel, 2010, Ghani \& Crow, 2017). The importance of self-assessment allows students to understand their learning goals and find out what they need to achieve (Mohd Faizal Nizam Lee Abdullah \& Leow Tze Wei, 2017).

\section{Objective}

The purpose of this study is to develop instrument questionnaire items and to determine the reliability and validity of attribute assessment instrument on communication skills, leadership skills and teamwork skills among UPSI students of Science Sports Program, Faculty of Sports Science and Coaching.

\section{METHODOLOGY}

Methodology of this study focuses on the study design, study population and sample, conceptual framework, research instrumentation, pilot study, data collection procedures, and data analysis procedures.

\section{Research Design}

This study is a quasi-experimental design using one group post-test only method (Ary, Jacobs \& Razavieh, 2002). The study is divided into three stages. The first stage aims to create an assessment instrument questionnaire and to obtain validity of content experts as well as field experts. The second stage seeks to obtain reliability of the attribute assessment instrument on communication skills, leadership skills and teamwork skills. While the third stage attempts to obtain validity of the items to ensure that each item represents the component of communication skills, leadership skills and teamwork skills.

\section{Sample}

All male and female students from first semester to eighth semester in Semester 1, Session 20182019 who are currently attending all courses offered at the Faculty of Sports Science and Coaching in UPSI are considered population of this study. Sample size selection for this study is based on Power Tables for Effect Size from Cohen (1992), with the sampling power value of .80, the effect of size (d) . 30 , the power of .80 and the significant level at $\alpha=.05$. Based on the formula, the sample size should be 175 people. However, the researchers used a sample size of 212 (125 $=$ men, $75=$ female) after considering the absence or mortality factor (Tuckman \& Waheed, 1981) that could possibly happen. All study samples were randomly selected.

\section{Variables}

In this study, dependent variables are scores on communication skills, leadership skills and teamwork skills. While independent variables are gender and type of programs followed by students at the Faculty of Sports Science and Coaching, UPSI. Figure 3.1 below shows the study variables. 


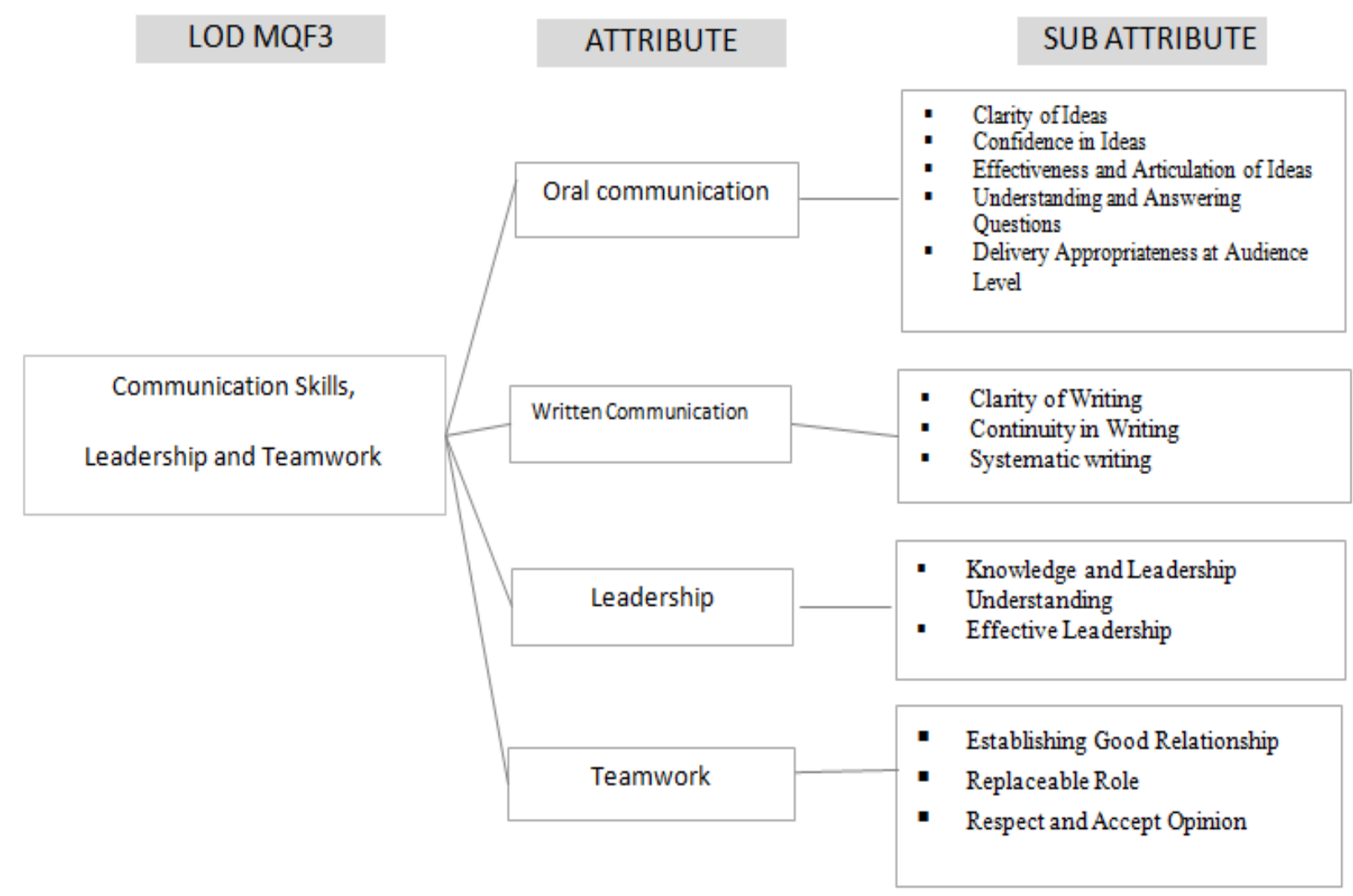

\section{Instrument}

Figure 3.1: Study Variables

The researchers have adapted and modified the assessment instrument in the form of scale review (ICGPA, MHE 2015) to five scaled questionnaires ( 1 = very weak, 2 = weak, 3 = satisfactory, $4=$ good and 5 = very good) for each constructed items on communication skills, leadership skills and teamwork skills. A total of 65 questionnaire items were created at the early stage of this study assessment and tested in actual studies A number of 212 subjects were used in the actual study to test the validity and reliability of the instrument items.

\section{Data Analysis Procedures}

Data obtained from the questionnaires will be analyzed using the SPSS 20.0 (Statistical Package for Social Science 20.0) software. Data analysis from the first part of this study was conducted using the Pearson Product Moment correlation statistic method to obtain validity of field experts based on agreement of two expert panels. The researchers used the Cronbach's alpha analysis to obtain reliability and consistency of the questionnaire instrument items. The factor analysis method is used to obtain validity of isolated construct, and to ensure that each item is placed in the proper component (Ahmad, 2014).

\section{RESULTS}

With reference to a study by Sidek Mohd Noah \& Jamaludin Ahmad (2005), for expert panel evaluation on 10 questionnaires being valued at scale 1 to 5 to verify the instrument of questionnaire, the value of validity obtained will be $r=, 93$. A total of 65 questionnaires have 
been developed to assess the performance of attributes namely communication skills, leadership skills and teamwork skills with four sub components. They are oral communication, written communication, leadership and teamwork. Following the analysis, only 59 items are valid. Cronbach's alpha analysis shows that the reliability value of communication skills questionnaire, leadership skills and teamwork skills in this study is $r=.87$. Table 1,2 and 3 show the results of factor analysis.

Table 1. Barlett's and Kaiser-Meyer-Olkin test results

\begin{tabular}{lll}
\hline $\begin{array}{l}\text { Kaiser-Meyer-Olkin Measure of } \\
\text { Sampling Adequency }\end{array}$ & .887 \\
\hline Barlett's Test of Sphericity & Approx. Chi Square & 11232.868 \\
& Df & 2080 \\
& Sig. & .000 \\
\hline
\end{tabular}

Kaiser's criterion technique was used to determine the number of components. Components with only one or more eigenvalue were selected in this analysis. There were four analysis components with more than one eigenvalue. Finding in Table 1 shows the results of all the 65 components analysed with 89.00 per cent variance. The matrix component shows loading in each line expressed each survey item's correlation with sub attribute comprising oral communication, written communication, leadership and teamwork.

Table 2. Total Variance Explained

\begin{tabular}{llcc}
\hline Component & \multicolumn{3}{l}{ Rotation Sums of Squared Loadings } \\
Total & \% of Variance & Cumulative \% \\
\hline 1 & 11.135 & 17.130 & 17.130 \\
2 & 11.087 & 17.056 & 34.187 \\
3 & 8.559 & 13.168 & 47.354 \\
4 & 4.100 & 6.308 & 53.662 \\
\hline
\end{tabular}

Extraction Method: Principal Component Analysis

To maintain all the four components for next analysis, the researchers has used varimax rotation method to minimize number of survey items with high correlation on each factor. According to Tabachnick and Fidell (2007) in their work, results that are based on orthogonal rotation can be easily translated and reported. Table 2 shows the result of four components rotation using the varimax rotation method. The findings show that the first component explained 17.13 per cent of variance, the second component explained 17.06 per cent of variance, third component explained 13.17 per cent variance and fourth component explained 6.31 per cent variance. Total amount of variant available which could be explained by all the five components was 53.66 per cent variance and the figure remained after rotation.

Table 3 shows the loading for each survey item for sub attributes namely verbal communication, written communication, leadership and teamwork. Based on Principal Component Analysis, from the overall 65 survey items only 59 items showed high communality 
score. Component line one, represented assessment instrument of sub attributes on verbal communication, written communication, leadership and teamwork which measures the first line sub attribute of oral communication skills. The second line represented assessment instrument on written communication skills. The third line represented assessment instrument on leadership skills and finally the fourth line, teamwork skills. Selection of construct component for all sub attributes in this study was based on high main loading and it exceeds the correlation coefficient value $r=0.50$. This is because high correlation value of a test on a measured factor indicated close relation with the factor. According to a study by Pallant (2005), based on this significant finding, 59 items in this analysis are considered valid for the attribute assessment on communication skills, leadership and teamwork in this study.

Table 3. Construct Validity for Rotated Component Matrix Component

\begin{tabular}{|c|c|c|c|c|}
\hline & \multicolumn{4}{|c|}{ Component } \\
\hline & 1 & 2 & 3 & 4 \\
\hline s32c & .785 & & & \\
\hline $\mathrm{s} 52 \mathrm{c}$ & .772 & & & \\
\hline $\mathrm{s} 12 \mathrm{c}$ & .764 & & & \\
\hline$s 42 c$ & .756 & & & \\
\hline s37c & .735 & & & \\
\hline s47c & .730 & & & \\
\hline s7c & .719 & & & \\
\hline$s 22 c$ & .717 & & & \\
\hline s27c & .704 & & & \\
\hline s38c & .673 & & & \\
\hline s53c & .642 & & & \\
\hline$s 23 c$ & .623 & & & \\
\hline s57c & .616 & & & \\
\hline$s 63 c$ & .609 & & & \\
\hline s17c & .593 & & & \\
\hline s18c & .581 & & & \\
\hline$s 28 c$ & .580 & & & \\
\hline$s 2 c$ & .574 & & & \\
\hline s33c & .569 & & & \\
\hline$s 13 c$ & .540 & & & \\
\hline s58c & .528 & & & \\
\hline $\mathrm{s} 8 \mathrm{c}$ & .509 & & & \\
\hline s43c & .500 & & & \\
\hline s10c & & .795 & & \\
\hline$s 20 c$ & & .779 & & \\
\hline s15c & & .771 & & \\
\hline s14c & & .761 & & \\
\hline$s 35 c$ & & .748 & & \\
\hline$s 25 c$ & & .747 & & \\
\hline
\end{tabular}


International Journal of Academic Research in Progressive Education and Development Vol. 8, No. 1, 2019, E-ISSN: $2226-6348$ @ 2019 HRMARS

\begin{tabular}{lll} 
s5c & .721 \\
s24c & .716 & \\
s9c & .705 & \\
s50c & .652 & \\
s29c & .647 & \\
s19c & .633 & \\
s4c & .612 & \\
s45c & .603 & \\
s40c & .598 & \\
s44c & .582 & \\
s34c & .576 & \\
s3c & .567 & \\
s49c & .564 & \\
s11c & & .858 \\
s16c & & .847 \\
s56c & & .817 \\
s26c & & .811 \\
s21c & & .793 \\
s46c & & .778 \\
s31c & & .771 \\
s51c & & .771 \\
s61c & & .759 \\
s41c & & \\
s6c & & \\
s1c & & \\
s62c & & \\
s65c & & \\
s55c & & \\
s64c & & \\
s60c & & \\
\hline Extraction Method: Principal Component Analysis. \\
Rotation Method: Varimax with Kaiser Normalization. \\
a. Rotation converged in 6 iterations. \\
s
\end{tabular}

\section{DISCUSSION}

Certain test instruments must be measured using several statistical methods to ensure a consistent and reliable test instrument. As supported by Baumgartner and Chung (2001), they stated that an instrument with construct validity is a valid and reliable instrument and could be used on any population that is being tested. Having formed 59 out of 65 instrument assessment items on communication skills, leadership skills, and teamwork that are valid and reliable, hence this study will be able to provide accurate information and feedback to the Faculty of Sports Science and Coaching to improve any shortcomings for better outcome in the future. 


\section{Conclusion}

The findings show that all the outlined features on attributes of communication skills, leadership skills and teamwork skills can be evaluated based on the instrument of this research questionnaire. All of the instrument items obtained high reliability value which is $r=.93$ were validated using factor analysis statistics. A total of validated 59 questionnaire items were obtained for attribute assessment on communication skills, leadership skills and teamwork skills. Instruments of this research questionnaire can be used by all UPSI lecturers at the Faculty of Sports Science and Coaching to assess performance of learning outcome domain on communication attributes, leadership skills and teamwork skills of students throughout the study semester.

\section{Acknowledgement}

This study was part of research funded by the Sultan Idris Education University (Code: GPU 20180057-107-01).

\section{References}

Hashim, A. (2014). Panduan analisis data secara efisien. Bandar Baru Bangi: Dubook Press Sdn. Bhd.

Hashim, A. (2015). Pengujian, pengukuran dan penilaian Pendidikan Jasmani. Bandar Baru Bangi: Dubook Press Sdn. Bhd.

Ary, D., Jacobs, L. C., \& Razavieh, A. (2002) Introduction to research in education (6th ed). Belmont, CA: Wadsworth/Thomson Learning.

Baumgatner, T. A., \& H.Chung. (2001). Confidence limits for intraclass reliability coefficients. Measurement in Physical Education and Exercise Science 5: 179-188.

Cohen, J. (1992). A power primer. Psychological bulletin, 112(1), 155.

Gardner, H. (2006). Multiple Intelligences: New Horizons. London: Basic Books.

Ghani, M. F. A., \& Crow, G. M. (2017). amalan komuniti pembelajaran profesional: perspektif pemimpin sekolah cemerlang negara maju. JuKu: Jurnal Kurikulum \& Pengajaran Asia Pasifik, 1(3), 10-27.

Hamat, M. F., \& Nordin, M. K. N. C. (2012). Tinjauan kepentingan pembangunan modal insan di Malaysia (Review on the Importance of Human Capital Development in Malaysia). Jurnal AlTamaddun Bil, 7(1), 75-89.

Jalii, A., Azyani, N., \& Esa A. (2012). Kemahiran menyelesaikan masalah menerusi aktiviti kokurikulum (khidmat masyarakat) dalam kalangan pelajar. Universiti Tun Hussein Onn Malaysia. 
Jalil, N. (2014). Kecenderungan pelajar cemerlang akademik terhadap pemilihan bidang PTV. (Doctoral dissertation, Universiti Tun Hussein Onn Malaysia).

Kementerian Pengajian Tinggi (2015). Pelan Pembangunan Pendidikan Malaysia 2015-2025 (Pendidikan Tinggi). Putrajaya: Kementerian Pendidikan Malaysia.

Kementerian Pengajian Tinggi (2016). Panduan Pentaksiran Hasil Pembelajaran. Putrajaya: Kementerian Pengajian Tinggi.

Maskan, N. (2013). Pelaksanaan pentaksiran berasaskan sekolah (PBS) bagi Mata Pelajaran Sains di Sekolah Kebangsaan Daerah Pontian, Johor (Doctoral dissertation, Universiti Tun Hussein Onn Malaysia). modal-insan-perlu-relevan\#ixzz2h0wRHI6J

Mohamad, H., \& Esa, A. (2013). Pembangunan modal insan holistik pelajar menerusi aktiviti kokurikulum. Universiti Tun Hussein Onn Malaysia.

Mohd Faizal Nizam Lee Abdullah \& Leow Tze Wei (2017). Kesahan dan kebolehpercayaan instrumen penilaian kendiri pembelajaran geometri tingkatan satu. Malaysian Journal of Learning and Instruction: Vol. 14, No. 1 (2017): 211-26.

Musa, W. A., \& Othman, R. (2014). Kesedaran Kendiri Terhadap Aktiviti Kokurikulum dan Keberkesanannya Kepada Remaja. Proceeding of the Social Sciences Research ICSSR, 9-10.

Pallant, J. (2005). SPSS survival manual (2nd edI). NewYork, NY: McGraw-Hill.

Prihamdani, D. (2016). Pengaruh komunikasi keluarga terhadap penguasaan Bahasa Inggeris peserta didik kelas $x$ di SMK Pgri 1 Tambun Kecamatan Tambun Selatan Kabupaten Bekasi. Jurnal Sekolah Dasar, 1(1).

Rinaldi, R., Hamzah, M. I., \& Nordin, N. M. (2015). Knowledge and attitude of lecturers toward usage of multimedia in teaching. Scientific Journal of PPI-UKM, 2(7), 300-302.

Sidek Mohd Noah \& Jamaludin Ahmad (2005). Pembinaan modul: Bagaimana membina modul latihan dan modul akademik. Serdang: Universiti Putra Malaysia.

Tabachnick, B. G., \& Fidell, L. S. (2007). Using multivariate statistics (5th ed.). Bosrom: Pearson Educational, Inc.

Tuckman, B. W., \& Waheed, M. A. (1981). Evaluation an individualized science programme for community college students. Journal of Research in Science Teaching, 18, 489-495.

Yassin, M. (2013). Keseimbangan Modal Insan Perlu Relevan. Utusan Online. Retrived from: http://www.utusan.com.my/utusan/Dalam_Negeri/20130402/dn_02/Keseimbangan- 